\title{
PEMBELAJARAN BERBICARA BERBANTUAN KOMIK STRIP UNTUK PEMBELAJAR BIPA KOREA SELATAN
}

\author{
Aswan \\ hikayatashwansha@upi.edu \\ Universitas Pendidikan Indonesia, Bandung
}

\begin{abstract}
Speaking skill is a very complex skill because it involves other skills. Especially in BIPA learning, relevant strategies are needed as an alternative to learn BIPA. Therefore, this study is intended to describe the results of learning process by using comic strip toward speaking practice. Based on the tracing of previous studies, it was not found any research related to the use of comic strips in learning to speak BIPA. The method used in this research is qualitative. The participants in this study were South Korean BIPA learners in intermediate levels of ability. The results of the data analysis show that learning to speak using comic strip can be an alternative in teaching BIPA. This can be seen in all activities which run effectively. In addition, learners also give very positive responses during learning.
\end{abstract}

Keywords : speaking learning; comic strip; BIPA; South Korea

Berbicara mengenai BIPA (Bahasa Indonesia untuk Penutur Asing) memang sudah tidak asing lagi dalam dunia pengajaran bahasa Indonesia saat ini. BIPA merupakan program pembelajaran bahasa yang dirancang secara khusus untuk pembelajar asing yang ingin belajar bahasa Indonesia. Desain pengajaran BIPA biasanya disesuaikan dengan kebutuhan pembelajar asing (Suyitno, dkk. 2017). Secara umum, karakteristik pembelajar BIPA adalah belajar bahasa sesuai kebutuhan. Beberapa pembelajar hanya mau belajar materi yang mereka butuh saja (Kusmiatun, 2016). Oleh sebab itu, pengajar BIPA harus selektif dalam memilih bahan ajar, mencari strategi pembelajaran, dan menentukan media yang tepat sasaran. Hal ini berarti, pengajar tidak boleh menyamakan strategi pembelajaran untuk penutur jati dengan penutur asing karena kedua penutur tersebut memiliki karakteristik yang berbeda.

Menurut Kusmiatun, dkk. (2017) setiap tahun pembelajar asing yang mempelajari bahasa Indonesia meningkat drastis. Pembelajar asing yang belajar bahasa Indonesia menyebar dari tingkat sekolah menengah sampai tingkat universitas. Perkembangan tersebut diamati dari berbagai lembaga yang menyediakan program beasiswa untuk pembelajar asing yang ingin belajar bahasa Indonesia. Mustakim, dkk. (2020) 
menyatakan kurang lebih 36 negara dan 130 institusi yang mengakui bahasa Indonesia sebagai bahasa yang wajib dipelajari di negara tersebut. Selain itu, ada juga yang memiliki inisiasi sendiri dalam balajar bahasa Indonesia seperti datang langsung ke Indonesia. Hal ini sejalan dengan asumsi dari Noviana (2018) bahwa secara umum orang asing yang mempelajari bahasa Indonesia memiliki dua tujuan, yaitu tujuan akademis dan tujuan praktis.

Salah satu keterampilan berbahasa yang penting untuk dikuasai bagi penutur asing adalah keterampilan berbicara. Keterampilan berbicara ini merupakan keterampilan yang sangat kompleks karena melibatkan aspek lain seperti menyimak, pengetahuan kosakata, dan sebagainya. Hal ini sesuai dengan pernyataan Wahyono dan Farahsani (2017) bahwa pembelajar BIPA mengalami beberapa kesulitan dalam berbicara. Kesulitan-kesulitan tersebut antara lain, adanya perbedaan struktur antara bahasa ibu pembelajar asing dengan bahasa Indonesia, penggunaan tingkat tutur dalam bahasa Indonesia, dan adanya campur kode bahasa Indonesia dan bahasa daerah dalam berkomunikasi. Salah satu upaya dalam mengatasi masalah tersebut adalah dengan membuat strategi pembelajaran bahasa dengan pendekatan proses yang dapat mengasah kemampuan pembelajar. Misalnya, membuat model-model pembelajaran berbicara menggunakan media yang praktis.

Adapun penelitian-penelitian terdahulu yang menggunakan komik strip di antaranya penggunaan komik strip dalam pembelajaran daring (Burns, 2018); pemanfaatan komik strip untuk pembelajaran menulis teks naratif (Megawati \& Anugerah, 2012; penggunaan komik strip untuk pembelajaran bahasa asing di SMP (Rokhayani \& Utari, 2014); pemanfaatan komik untuk pembelajaran membaca pemahaman (Merc, 2013); penggunaan komik strip untuk menambah kreativitas dalam pembelajaran bahasa (Kohnke, 2019); penerapan komik strip untuk pembelajaran bahasa dalam meningkatkan kosakata (Darsalina, dkk., 2016); penggunaan komik strip untuk pembelajaran bahasa untuk penutur asing (Tarabuzan \& Popa, 2019) (Saifudin, 2017); pengembangan komik strip berbasis kebudayaan Kalimantan untuk pembelajaran membaca (Noviaty \& Rosnija, 2017); penggunaan komik strip untuk pembelajaran tata bahasa (Akkaya, 2013); pemanfaatan komik strip untuk pembelajaran membaca teks deskriptif (Pradana, 2017); penggunaan komik strip untuk pembelajaran menulis kreatif (Selong, dkk., 2021); dan penggunaan komik strip untuk metode penerjemahan dalam meningkatkan kosakata siswa (Priatin, dkk. 2021). 
Aswan Aswan, Pembelajaran Berbicara Berbantuan Komik Strip Untuk Pembelajar BIPA Korea Selatan

Berdasarkan telaah lebih lanjut dari penelitian tersebut, belum ditemukan penelitian yang mendalam terkait penggunaan komik strip dalam pembelajaran berbicara, khususnya dalam konteks ke-BIPA-an. Penelitian-penelitian terdahulu yang secara khusus di bidang pengajaran BIPA di antaranya strategi debat aktif dengan media komik (Yunita, 2017); penerapan media komik pada pembelajaran BIPA Korea Selatan (Ramliyana, 2016a); membangkitkan motivasi penutur asing melalui media komik (Ramliyana, 2016b); dan pemanfaatan media komik sebagai upaya peningkatan penguasaan kosakata pembelajar BIPA (Ramliyana, 2016c). Penelitian-penelitian ini menggunakan komik secara umum sedangkan peneliti menggunakan komik strip. Jadi, dapat disimpulkan bahwa masih sangat sedikit yang menggunakan komik strip ke dalam pembelajaran berbicara BIPA.

Berdasarkan penelitian dan fenomena yang sudah dijelaskan, penelitian ini bertujuan untuk memanfaatkan komik strip dalam kegiatan pembelajaran berbicara untuk pembelajar BIPA Korea Selatan. Agar bahasan di dalam penelitian ini tidak terlalu melebar, peneliti membatasi beberapa hal di dalam penelitian ini. Pertama, penelitian ini hanya memaparkan bagaimana konsep pembelajaran berbicara berbantuan komik strip. Kedua, peneliti memaparkan hasil berdasarkan kegiatan pembelajaran di lapangan. Ketiga, hasil akhir dikuatkan dengan respons partisipan di dalam penelitian ini sehingga hasil tidak bersifat subjektif. Hal-hal yang tidak diteliti adalah tingkat kemampuan berbicara pembelajar BIPA, efektivitas secara kuantitatif penggunaan komik strip, dan hubungan perilaku pembelajar dengan kebermanfaatan strategi pembelajaran. Jadi, dapat dikatakan bahwa penelitian ini hanya berfokus untuk mendeskripsikan konsep penerapan pembelajaran berbicara berbantuan komik strip di lapangan. Penelitian ini dilakukan karena pembelajaran berbicara merupakan aktivitas yang sangat kompleks. Kemampuan berbicara seyogianya dimiliki oleh semua manusia normal. Namun, keterampilan berbicara belum tentu dimiliki oleh setiap manusia (Tambunan, 2018).

\section{Pembelajaran Berbicara}

Tarigan (1983) mendefinisikan berbicara adalah keterampilan yang menuntut seseorang mengutarakan bunyi-bunyi artikulasi. Selain itu, kegiatan berbicara juga adalah kemampuan untuk mengekspresikan perasaaan atau menyampaikan gagasan. 
Sederhananya, seseorang yang dinyatakan terampil berbicara adalah orang yang mampu berbicara dalam situasi apa pun, di mana saja, dan kapan saja. Maidar dan Mukti (1991) menyatakan bahwa tujuan utama seseorang berbicara adalah untuk melakukan komunikasi dan menyampaikan pesan secara efektif. Kegiatan berbicara ini sangat erat kaitannya dengan keterampilan menyimak. Sejalan dengan hal tersebut, Halim (1974) mengungkapkan bahwa keterampilan berbicara merupakan keterampilan yang sangat kompleks karena melibatkan berbagai unsur-unsur bahasa lainnya. Misalnya, kemampuan melafalkan kosakata, pengetahuan tata bahasa, dan sebagainya. Berdasarkan hal-hal yang sudah dipaparkan bahwa keterampilan berbicara adalah keterampilan yang sangat penting dipelajari karena fungsinya sebagai alat komunikasi. Selain itu, keterampilan ini juga harus didukung oleh unsur-unsur kebahasaan lainnya.

Keterampilan berbicara memiliki hubungan yang sangat erat dengan pembelajaran berbicara. Keterampilan berbicara yang baik akan lahir dari pembelajaran berbicara yang baik pula. Menurut Abidin (2013) pembicaraan dapat berjalan dengan baik apabila pengajar mampu memahami prinsip-prinsip pembelajaran berbicara. Adapun prinsipprinsip dalam pembelajaran berbicara menurut Abidin (2013) adalah sebagai berikut ini.

1) Pembelajaran berbicara diharapkan mampu membentuk kematangan psikologis pembelajar dalam berbicara. Artinya, melalui kegiatan berbicara harus membentuk psikologis pembelajar secara efektif.

2) Pembelajaran berbicara harus melibatkan pembelajar dalam berbagai konteks. Hal ini dapat menuntut siswa memperoleh berbagai kosakata sesuai konteks tersebut.

3) Pembelajaran berbicara harus dipola agar interaktif dan mampu menstimulus pembelajar dalam berbicara.

4) Pembelajaran berbicara harus dibekali dengan strategi berbicara yang tepat sasaran.

5) Pembelajaran berbicara dapat diukur dan dipraktikkan secara langsung di dalam kelas maupun di luar kelas.

6) Pembelajaran berbicara harus dipantau oleh pengajar secara kontinu agar dapat diketahui perkembangan kemampuan siswa.

7) Pembelajaran berbicara harus diorientasikan pada pembentukan kemahiran dan membentuk siswa menjadi pembicara yang kreatif. 
Aswan Aswan, Pembelajaran Berbicara Berbantuan Komik Strip Untuk Pembelajar BIPA Korea Selatan

Menurut Linda, dkk. (1996) bahwa pengajar harus benar-benar memerhatikan model dan strategi dalam pembelajaran berbicara. Model atau strategi yang tepat dalam pembelajaran berbicara memiliki dampak yang signifikan dalam keterampilan bebicara pembelajar. Jadi, dapat dikatakan bahwa titik keberhasilan dalam pembelajaran berbicara dapat dilihat dari aspek penetapan model dan strategi yang dilakukan oleh guru yang disesuaikan juga dengan prinsip-prinsip pembelajaran berbicara.

\section{Komik Strip}

Komik strip merupakan komik yang sangat sederhana dibandingkan dengan bentuk komik lainnya. Nurgiyantoro (2010) menyatakan bahwa komik strip adalah komik yang didesain hanya terdiri dari beberapa panel gambar saja. Meskipun demikian, komik strip memiliki isi yang dapat mengungkapkan pokok pikiran secara utuh. Artinya, komik strip adalah komik yang sangat sederhana tetapi mampu mengungkapkan gagasan secara utuh. Hal ini disebabkan gambar pada komik strip tidak banyak dan biasa hanya berfokus pada satu topik pembicaraan. Topik-topik yang biasa diangkat di dalam komik strip adalah peristiwa dan isu muktahir (Mulyati, 2016). Sejalan dengan itu, Pritandhari (2016) mengungkapkan bahwa komik strip terdiri atas gambar-gambar yang membentuk sebuah kisah berdasarkan isu-isu menarik yang diadaptasi oleh pembuatnya.

Secara umum komik yang beredar di Indonesia dibagi menjadi lima jenis yaitu web komik, novel grafis, komik kompilasi, buku komik, dan komik strip. Namun, tidak dapat dimungkiri bahwa dari kelima jenis komik tersebut, komik strip menjadi primadona dan sering ditemui di media sosial atau di surat kabar. Keunikan dari komik strip adalah dari sisi bentuknya. Komik strip dapat tersusun dari empat panel dari sekali terbit. Dari sisi gambar, pembuat komik mendesain dalam bentuk kartunal serta berorientasi pada isu yang sedang dibicarakan. Komik strip yang populer di masyarakat adalah Tahilalats (Maharsi, 2011).

Menurut Ega, dkk. (2014), perancangan komik strip sebagai media pembelajaran harus disesuaikan dengan tren yang sedang populer. Dalam komik strip, unsur-unsur humor sangat sering ditemukan oleh siapa saja. Unsur humor ini bertujuan untuk menghibur sekaligus mengedukasi pembaca. Tidak dapat dimungkiri bahwa unsur-unsur humor ini tidak dapat lepas dari dunia perkomikan (Saifudin, dkk. 2019). Biasanya di 
dalam komik strip pembaca diajak berpikir oleh pembuat komik. Secara sederhana, perencanaan komik ini harus berguna dan harus menampilkan sisi edukasi. Hal tersebut sejalan dengan asumsi dari Rohani (2014) bahwa komik dapat dijadikan sebagai media pembelajaran yang memberikan sisi positif dan edukatif. Selain itu, komik strip sangat praktis jika dilihat dari bentuknya yang sangat sederhana. Tidak hanya hiburan semata, komik strip juga harus memberikan pengalaman pembelajaran yang bersifat personal dan tidak memaksa. Artinya, konten-konten di dalam komik strip biasanya dapat diterima secara universal.

\section{METODE PENELITIAN}

Metode yang digunakan dalam penelitian ini adalah kualitatif. Metode ini dipilih karena disesuaikan dengan tujuan penelitian yang ingin menggambarkan dan menjelaskan aktivitas pembelajaran berbicara menggunakan media komik strip. Hal tersebut sejalan dengan pernyataan dari Sugiarto (2017) bahwa seorang peneliti memilih metode kualitatif disebabkan peneliti ingin mengungkapkan masalah secara holistik dan konstekstual. Sederhananya, dalam penelitian ini tidak menggunakan analisis statistik melainkan analisis deskriptif.

Partisipan di dalam penelitian ini adalah pembelajar BIPA asal Korea Selatan. Partisipan adalah pembelajar BIPA dengan tingkat kemampuan menengah dengan asumsi pembelajar sudah dapat berbicara bahasa Indonesia tetapi masih belum terlalu fasih. Pada tingkat tersebut, pembelajar perlu banyak latihan bersama penutur asli bahasa Indonesia agar dapat terampil berbicara bahasa Indonesia dalam konteks yang berbeda-beda. Partisipan berjumlah dua orang.

Tahapan dalam penelitian ini dimulai dari menentukan masalah, mencari dan membaca teori, melaksanakan penelitian, mengolah data, dan membuat kesimpulan. Langkah awal adalah peneliti menentukan masalah yang ingin dikaji dan diberi batasanbatasan agar penelitian ini lebih terfokus pada poin-poin tertentu. Proses mencari dan membaca teori sangat dibutuhkan agar peneliti mengetahui dan memahami variabel yang diteliti secara mendalam sehingga data yang dianalisis tepat sasaran. Adapun pada pelaksanaan penelitian dilakukan pembelajaran berbicara berbantuan komik strip. Setelah itu, peneliti melakukan analisis secara mendalam terkait data yang diteliti. Kemudian, terakhir adalah membuat kesimpulan terkait masalah yang diteliti. 
Aswan Aswan, Pembelajaran Berbicara Berbantuan Komik Strip Untuk Pembelajar BIPA Korea Selatan

Teknik pengumpulan data dilakukan menggunakan observasi, dokumentasi, dan wawancara. Teknik observasi digunakan sebagai upaya peneliti dalam melihat aktivitas pembelajaran berbicara berbantuan komik strip. Teknik pengumpulan data dokumentasi digunakan sebagai catatan peneliti dalam menganalisis data. Adapun pada teknik wawancara digunakan untuk menguatkan hasil penelitian ini. Data dianalisis dengan tahapan mereduksi data, menganalisis data, dan membuat kesimpulan.

\section{HASIL DAN PEMBAHASAN}

\section{Konsep Komik Strip yang Dikembangkan}

Komik strip dirancang berdasarkan kebutuhan pembelajar BIPA. Sebelum dibuat komik yang ingin digunakan, peneliti melakukan analisis kebutuhan pembelajar BIPA melalui wawancara mendalam. Hal yang paling penting untuk diungkapkan adalah tujuan pembelajar BIPA belajar bahasa Indonesia. Hasil analisis masalah yang mendalam, ditemukan bahwa pembelajar BIPA yang menjadi partisipan dalam penelitian ini belajar bahasa Indonesia disebabkan kebutuhan pekerjaan. Artinya, pembelajar bertujuan untuk kerja di Indonesia sehingga konteks komik strip yang dibuat relevan dengan kebutuhan pembelajar. Agar menjadi lebih jelas tampak komik strip yang dibuat, perhatikan gambar berikut.
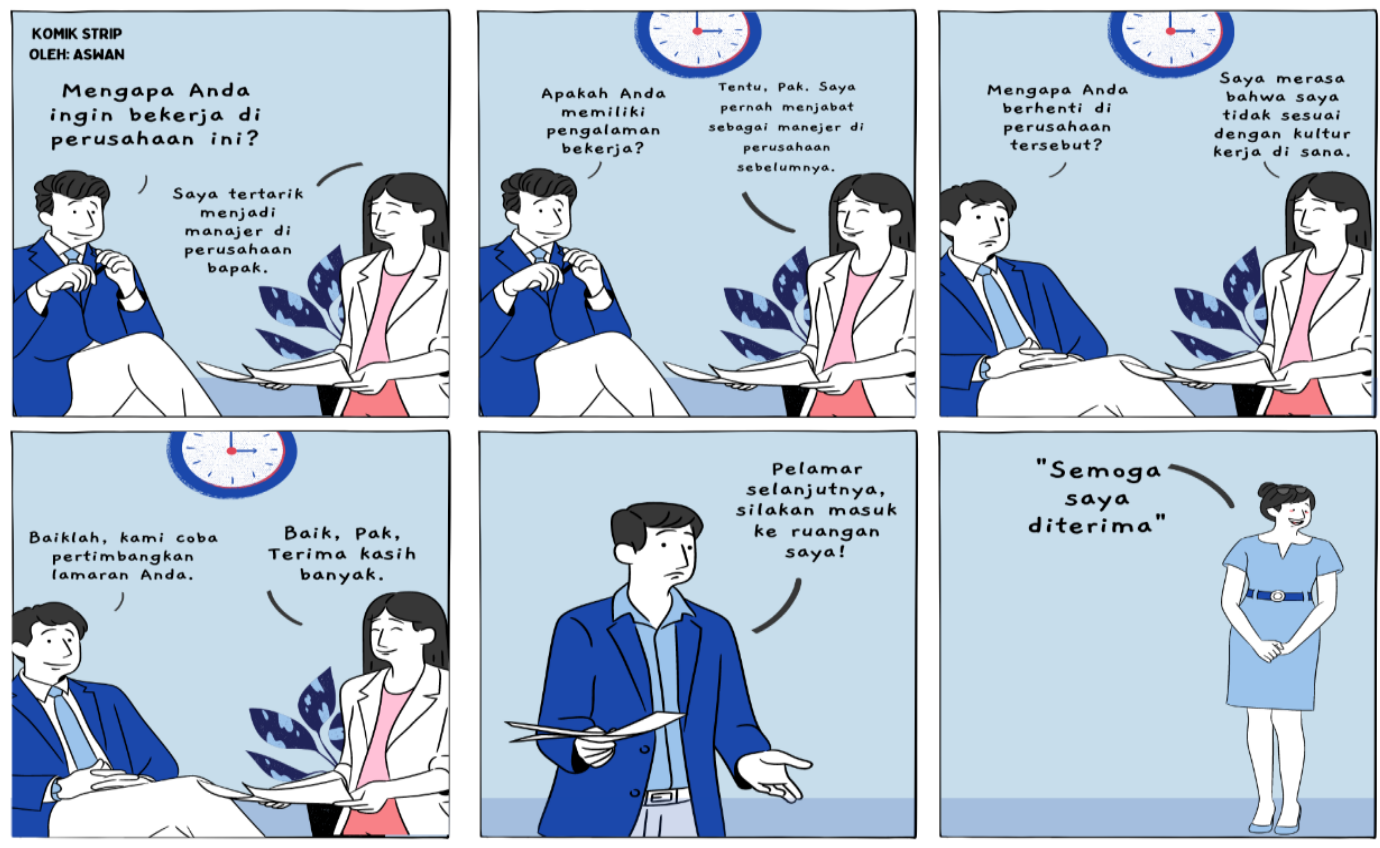

Gambar 1. Komik Strip Tema Melamar Pekerjaan 
Komik strip yang dibuat ini menggunakan aplikasi Canva secara daring. Langkahlangkah pembuatannya dimulai dari membuat teks dialog percakapan terlebih dahulu. Kemudian, mencari templete yang sesuai dengan konteks dialog. Jika sudah menemukan templete yang sesuai, peneliti memasukkan dialog dan mengubah sesuai kebutuhan dan pola gambar. Komik strip yang dibuat dengan tema melamar pekerjaan tidak ada unsur humor yang dimasukkan karena peneliti ingin berfokus pada konteks melamar pekerjaan secara formal. Hal ini disebabkan perbedaan budaya dan selera humor antara masyarakat Indonesia dan Korea Selatan sehingga pada tema melamar pekerjaan tidak dimasukkan unsur humor. Seperti yang tampak pada gambar 1 bahwa terdapat 2 tokoh utama yang ditampilkan pada komik tersebut, yaitu seorang bos milik perusahaan dan pelamar pekerjaan. Selain itu, peneliti juga menampilkan tokoh pendukung lainnya pada bagian akhir yakni pelamar pekerjaan lainnya. Secara umum, gagasan utama di dalam komik tersebut menampilkan seorang wanita yang ingin melamar pekerjaan. Konsep ini sejalan dengan tujuan pembelajar BIPA Korea Selatan yang bertujuan menjadi manajer di Indonesia. Namun, peneliti juga membuat tema lain agar pembelajaran tidak terlalu kaku. Berikut tampaknya.
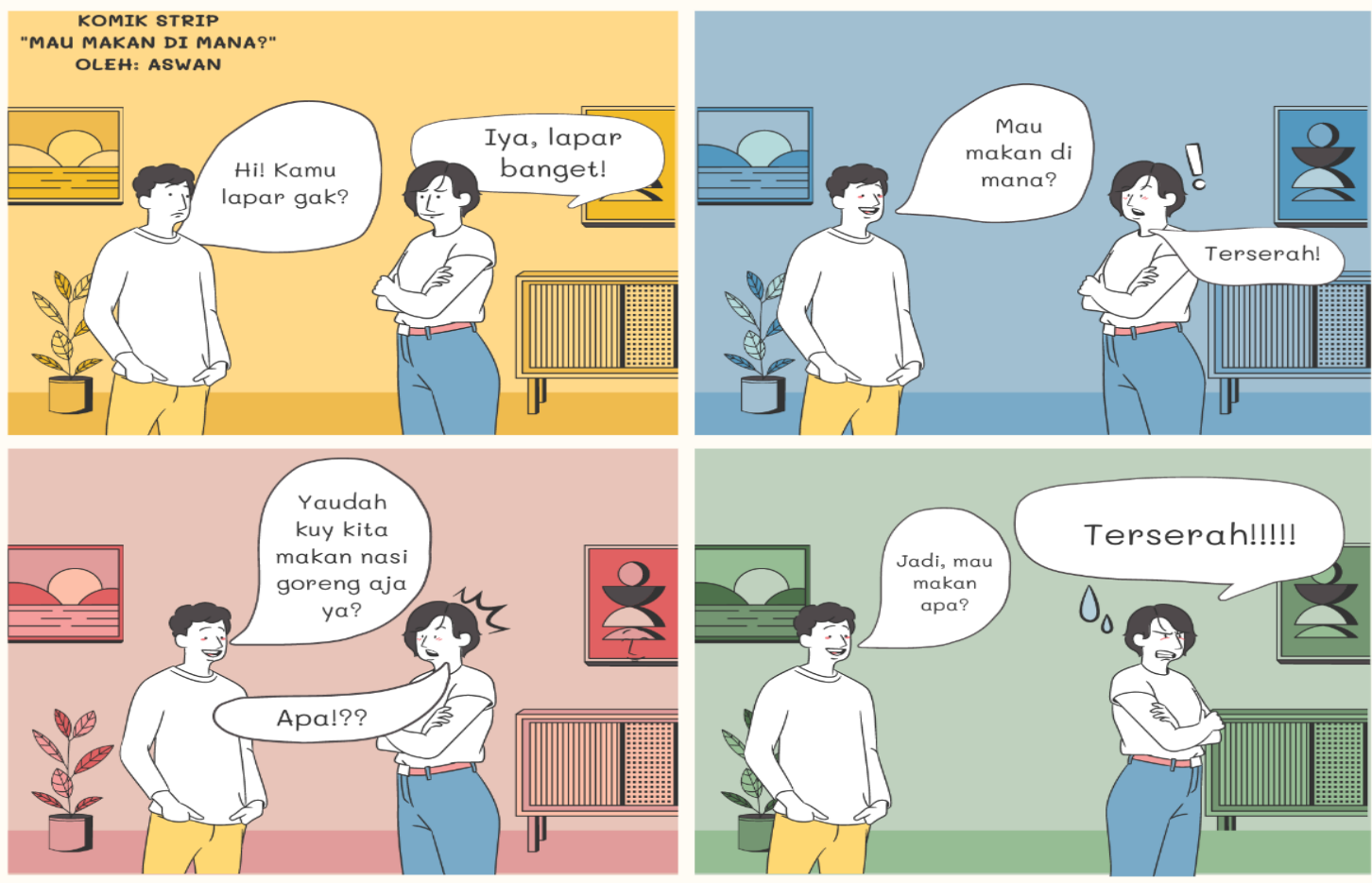

Gambar 2. Komik Strip Tema Memilih Tempat Makan 
Aswan Aswan, Pembelajaran Berbicara Berbantuan Komik Strip Untuk Pembelajar BIPA Korea Selatan

Perancangan komik kedua menggunakan tema memilih tempat makan. Tema ini berbeda dengan komik yang dirancang pada bagian sebelumnya. Tema pada komik strip gambar 2 di atas lebih santai dan tidak kaku. Ada unsur humor yang dimasukkan ke dalam komik strip pada gambar 2 tersebut. Humor dapat dilihat pada konteks secara umum yang digambarkan bahwa perempuan selalu sulit untuk menentukan pilihan tempat makan jika ditanya oleh mitra tutur. Hal ini merupakan kebiasaan yang sering terjadi di Indonesia. Komik strip seperti yang tampak pada gambar 2 ditampilkan dua tokoh utama yang sedang berdiskusi untuk menentukan pilihan makanan.

\section{Aktivitas Pembelajaran Berbicara Menggunakan Komik Strip}

Secara umum pembelajaran berbicara menggunakan komik strip dibagi menjadi tiga bagian yaitu pembukaan, inti, dan penutup. Ketiga bagian ini memiliki fungsi masing-masing di dalam pembelajaran. Agar menjadi jelas, berikut ditampilkan di dalam bentuk tabel.

Tabel 1. Kegiatan Pembelajaran

\begin{tabular}{cl}
\hline Pembukaan & Pada tahap ini, peneliti mempersiapkan kelas. Peneliti menanyakan \\
& kondisi dan kesiapan pembelajar dalam ikut serta dalam belajar. \\
& Setelah ada komunikasi yang terjalin, peneliti menanyakan materi \\
& yang sudah dipelajari pada pertemuan sebelumnya. Peneliti bersama \\
& dengan pembelajar mereviu kembali materi yang sudah dipelajari. \\
& Setelah materi yang sudah direviu bersama-sama, peneliti \\
& menjelaskan tujuan pembelajaran yang akan dilaksanakan dan yang \\
& harus dikuasai. \\
& Pembelajaran dimulai dengan memberi materi terlebih dahulu \\
& terkait tentang melamar pekerjaan. Peneliti menggunakan \\
& pendekatan saling respons, artinya peneliti memancing pembelajar \\
& untuk bercerita banyak hal terkait pekerjaan. Hal ini penting untuk \\
& dilakukan karena pembelajaran berbicara intinya adalah menuntut \\
& pembelajar untuk melakukan komunikasi dua arah. \\
& Setelah materi tersampai dengan baik, peneliti menampilkan \\
komik strip pada pembelajar. Pembelajar diminta untuk mengulas \\
\hline
\end{tabular}




terkait gagasan yang ada pada komik tersebut. Peneliti dan
pembelajar melakukan diskusi secara mendalam terkait tema
lamaran pekerjaan dan terkait memilih tempat makan di Indonesia.
Agar pembelajaran semakin mengesankan, pembelajar diminta
untuk memerankan tokoh yang ada di dalam komik strip tersebut
secara bergantian. Pada tahap ini, ada beberapa aktivitas yang
mendukung pembelajaran berbicara yaitu menyimak, membaca,
memahami kosakata, dll.
Akhir dari pembelajaran berbicara menggunakan komik strip ini
adalah dengan membuat simpulan secara bersama-sama terkait
materi ajar. Peneliti mengajak pembelajar untuk membuat simpulan
tekait materi yang sudah diajar. Selain itu, peneliti juga
memberitahu beberapa kelemahan pembelajar agar tidak diulangi di
masa yang akan datang. Pembelajaran ditutup dengan
menyampaikan materi yang akan diajarkan pada pertemuan
selanjutnya.

\section{Respon Partisipan}

Berdasarkan hasil wawancara, partisipan dalam penelitian ini mengungkapkan bahwa komik strip merupakan media yang sangat menarik. Daya tarik tersebut diungkapkan dari sisi ilustrasi, konten, dan kebermanfaatan media. Partisipan mengungkapkan bahwa ilustrasi dalam komik strip sangat menarik karena memiliki perpaduan warna yang tidak terlalu terang. Adapun dari segi konten, partispan mengatakan bahwa konten yang tidak terlalu banyak di dalam komik strip membuat pembelajaran lebih terfokus dan mudah dipahami. Selain itu, dari sisi kebermanfaatan media, partisipan mengungkapkan bahwa media komik strip sangat bermanfaat dalam membantu pembelajar terampil berbicara bahasa Indonesia.

\section{Temuan Penelitian}

Berdasarkan hasil analisis yang mendalam, ditemukan bahwa pembelajaran berbicara berbantuan komik strip dapat menjadi salah satu strategi dalam pembelajar BIPA. Hal ini dapat dilihat dari seluruh aktivitas yang berjalan secara efektif. Materi 
Aswan Aswan, Pembelajaran Berbicara Berbantuan Komik Strip Untuk Pembelajar BIPA Korea Selatan

tersampaikan dengan baik dan pembelajar dapat melakukan aktivitas berbicara. Aktivitas berbicara yang dimaksud adanya komunikasi dua arah yang terjali secara terus-menerus antara peneliti dengan pembelajar sesuai konteks. Adanya komik strip dapat memacu pembelajar dalam berbicara dan memahami materi secara komprehensif karena ditunjang dengan aktivitas lainnya seperti menyimak, membaca dialog, dan menulis hal-hal yang tidak dipahami selama pembelajaran berlangsung.

Temuan ini sejalan dengan temuan dari penelitian yang dilakukan oleh Pramesti, dkk. (2020); Saputro dan Haryadi (2018); Nadiyah, dkk. (2019); Surya, dkk. (2016); Kusnida, dkk. (2015); Wibowo dan Roysa (2018); Ariyanto dan Laksana (2017); Maghfirah dan Herowati (2017); Salam, dkk. (2018) yaitu komik strip memiliki banyak sekali manfaat baik di dunia pendidikan maupun sebagai tempat untuk kritik sosial. Adapun hal yang membedakan temuan penelitian tersebut dengan temuan penelitian ini adalah dari segi pemanfaatannya. Peneliti menggunakan komik strip ini untuk pembelajaran berbicara BIPA sedangkan penelitian-penelitian terdahulu mempunyai cakupan yang lebih luas. Artinya, penggunaan komik strip pada pembelajaran BIPA belum pernah dilakukan sehingga temuan ini menjadi salah satu terobosan dalam pengajaran ke-BIPA-an di Indonesia dan luar negeri.

\section{SIMPULAN}

Berdasarkan hasil dan pembahasan, simpulan yang dapat diambil dalam penelitian ini yaitu pembelajaran berbicara berbantuan komik strip dapat menjadi salah satu alternatif dalam pembelajaran berbicara BIPA, khususnya tingkat kemampuan menengah. Pembelajaran berbantuan komik strip ini dapat mengasah keterampilan berbicara pembelajar BIPA. Namun, penelitian ini masih penelitian dasar dan perlu dikembangkan lagi agar diketahui lebih lanjut keefektifan pembelajaran dan kemampuan pembelajar dengan menggunakan komik strip ini.

\section{REFERENSI}

Abidin, Y. (2013). Pembelajaran bahasa berbasis pendidikan karakter. Bandung: Refika Aditama. 
Akkaya, A. (2013). A different activity in grammar learning in Turkish course: Educational comic strips. International Journal of Academic Research, 5(5), $118-123$.

Ariyanto, A., \& Laksana, S. D. (2017). Pembelajaran IPS dengan media komik strip di kelas 4. Muaddib: Studi Kependidikan dan Keislaman, 7(2), 188-198.

Burns, M. T. (2018). Effective use of comic strip development in an online learning environment. Journal of Nutrition Education and Behavior, 50(7), 57.

Darsalina, L., Syamaun, A., \& Sari, D. F. (2016). The application of comic strips in teaching vocabulary. Research in English and Education Journal, 1(2), 137-145.

Ega. Zacky, A., \& Waluyanto, H. D. (2014). Perancangan komik strip untuk meningkatkan semangat kewirausahaan. Jurnal DKV Adiwarna, 1(4), 1-12.

Foulsham, T., Wybrow, D., \& Cohn, N. (2016). Reading without words: Eye movements in the comprehension of comic strips. Applied Cognitive Psychology, 30(4), 566579.

Halim, A. (1974). Ujian bahasa. Bandung: Ganaco CV.

Kohnke, L. (2019). Using comic strips to stimulate student creativity in language learning. TESOL Journal, 10(2), 1-5.

Kusmiatun, A. (2016). Mengenal BIPA (Bahasa Indonesia bagi Penutur Asing) dan pembelajarannya. Daerah Istimewa Yogyakarta: Penerbit K-Media.

Kusmiatun, A., Suyitno, I., Widodo, H. S., \& Basuki, I. A. (2017). Identifying features of Indonesian for speakers of other languages (BIPA) learning for academic purposes. International Journal of Social Sciences \& Educational Studies, 3(4), $197-204$.

Kusnida, F., Mulyani, M., \& Su'udi, A. (2015). Keefektifan penggunaan media audio visual dan media komik strip dalam pembelajaran menulis cerpen yang bermuatan nilai-nilai karakter berdasarkan gaya belajar. Seloka: Jurnal Pendidikan Bahasa dan Sastra Indonesia, 4(2), 111-117.

Linda C, Bruce C, \& Dee D. (1996). Teaching \& learning, through: Multiple intellegences. Boston: Allyn and Bacon.

Maghfirah, F., \& Herowati, H. (2017). Pengembangan media komik strip sains "pemanasan Global" untuk meningkatkan motivasi membaca siswa kelas VII SMPN 2 Sumenep. LENSA (Lentera Sains): Jurnal Pendidikan IPA, 7(2), 7684.

Maharsi, I. (2011). Komik dunia kreatif tanpa batas. Yogyakarta: Kata Buku. 
Aswan Aswan, Pembelajaran Berbicara Berbantuan Komik Strip Untuk Pembelajar BIPA Korea Selatan

Maindar G. A. \& Mukti U. S. (1991). Pembinaan kemampuan berbicara bahasa indonesia. Jakarta: Penerbit Erlangga.

Megawati, F., \& Anugerahwati, M. (2012). Comic Strips: A study on the teaching of writing narrative texts to Indonesian EFL students. Teflin Journal, 23(2), 183205.

Merc, A. (2013). The effect of comic strips on EFL reading comprehension. International Journal on New Trends in Education and Their Implications, 4(1), 54-64.

Mulyati, L. (2018). Penggunaan media komik strip dalam meningkatkan keterampilan menulis teks anekdot di SMK Negeri 1 Sumedang. Riksa Bahasa: Jurnal Bahasa, Sastra, dan Pembelajarannya, 2(2), 187-194.

Mustakim, M., Musdalifah, M., \& Elihami, E. (2020). Teaching indonesia language for Kun Shan University students and volunteering for campus guests from Indonesian Universities Tainan-Taiwan Roc. Maspul Journal of Community Empowerment, 1(1), 42-53.

Nadiyah, S., Wijaya, F. Y., \& Hakim, A. R. (2019). Desain komik strip matematika pada materi statistika untuk kelas VI tingkat sekolah dasar. JKPM (Jurnal Kajian Pendidikan Matematika), 4(2), 135-146.

Noviana, F. (2018). Pemerolehan bahasa dan budaya indonesia penutur asing melalui cerita rakyat. LITE: Jurnal Bahasa, Sastra, dan Budaya, 14(1), 1-10.

Noviaty, G., \& Rosnija, E. (2017). Designing a comic strip based on Kalimantan Barat folklore to support teaching reading. Jurnal Pendidikan dan Pembelajaran Khatulistiwa, 6(5). 1-15.

Nurgiyantoro, B. (2010). Sastra Anak Pengantar Pemahaman Dunia Anak. Yogyakarta: Gadjah Mada University Press.

Pradana, A. B. A. (2018). Comic strips for teaching descriptive reading. Britania Journal of English Teaching, 1(1).

Pramesti, U. D., Sunendar, D., \& Damayanti, V. S. (2020). Komik strip sebagai media pendidikan literasi kesehatan dalam pembelajaran bahasa indonesia pada masa pademi COVID-19. Bahterasia: Jurnal Ilmiah Pendidikan Bahasa Dan Sastra Indonesia, 1(2), 45-54.

Priatin, L. Y., Irianti, L., \& Nurfauziah, Z. (2021). Translating comic strips as a strategy to enrich students' vocabulary mastery. International Journal of Innovation and Education Research, 1(1), 1-8. 
Pritandhari, M. (2016). Penerapan komik strip sebagai media pembelajaran mata kuliah manajemen keuangan mahasiswa Universitas Muhammadiyah Metro. Jurnal Promosi: Jurnal Pendidikan Ekonomi UM Metro, 4(2), $1-7$.

Ramliyana, R. (2016a). Penerapan media komik pada pembelajaran BIPA (Studi Kasus pada peserta Korea tingkat pemula di Universitas Trisakti Jakarta). SAP (Susunan Artikel Pendidikan), 1(1), 8-17.

Ramliyana, R. (2016b). Membangkitkan motivasi belajar bahasa Indonesia bagi penutur asing (BIPA) melalui media komik. Dialektika: Jurnal Bahasa, Sastra, dan Pendidikan Bahasa dan Sastra Indonesia, 3(1), 1-19.

Ramliyana, R. (2016c). Media Komik sebagai upaya peningkatan penguasaan kosakata dalam pembelajaran bahasa indonesia bagi penutur asing (BIPA). Riksa Bahasa: Jurnal Bahasa, Sastra, dan Pembelajarannya, 2(2), 207-218.

Rohani, A. (2014). Media intruksional edukatif. Jakarta: Rineka Cipta.

Rokhayani, A., \& Utari, A. R. P. (2014). The use of comic strips as an English teaching media for junior high school students. Language Circle: Journal of Language and Literature, 8(2), 143-149.Saifudin, A. (2017). Penggunaan Manga Humor dalam Pembelajaran Bahasa dan Penelitian Bahasa Jepang. JAPANEDU: Jurnal Pendidikan dan Pengajaran Bahasa Jepang 2 (2), 99-113

Saifudin, A., Risagarniwa, Y. Y., Citraresmana, E., \& Sidiq, I. I. (2019). Pengembangan alat analisis humor dalam komik Jepang. Japanese Research on Linguistics, Literature, and Culture, 1(2), 129-143.

Salam, B., Prasetyo, I. J., \& Susilo, D. (2018). IInterpretasi dan makna kritik sosial dalam "komik strip untuk umum (Kostum)" Periode 1 Desember-31 Desember 2017. LONTAR: Jurnal Ilmu Komunikasi, 6(2), 96-110.

Saputro, G. E., \& Haryadi, T. (2018). Edukasi kampanye anti hoax melalui komik strip. Desain Komunikasi Visual, Manajemen Desain dan Periklanan (Demandia), 3(02), 238-255.

Selong, R. N., Olii, S. T., \& Rettob, A. (2021). Students'perception on the use of comic strips in creative writinG. Journal of English Language and Literature Teaching, $5(2), 79-85$.

Sugiarto, E. (2017). Menyusun proposal penelitian kualitatif: Skripsi dan tesis: Suaka Media. Daerah Istimewa Yogyakarta: Diandra Kreatif.

Surya, Ng, W., Agung. A., \& Cahyadi, J. (2016). Perancangan komik strip sebagai media layanan masyarakat untuk bijak dalam bersosial media. Jurnal DKV Adiwarna, $1(8), 1-11$. 
Aswan Aswan, Pembelajaran Berbicara Berbantuan Komik Strip Untuk Pembelajar BIPA Korea Selatan

Suyitno, I., Susanto, G., Kamal, M., \& Fawzi, A. (2017). Cognitive learning strategy of bipa students in learning the indonesian language. IAFOR Journal of Language Learning, 3(2), 175-190.

Tambunan, P. (2018). Pembelajaran keterampilan berbicara di sekolah dasar. Jurnal Curere, 2(1), 1-11.

Tarabuzan, E. O. \& Popa, N. L. (2015). Using comic strips in teaching and learning French as foreign language: Changes in motivational beliefs. Review of Artistic Education, 9(10), 273-278.

Tarigan, H. G. (1983). Strategi pengajaran dan pembelajaran berbahasa. Bandung: Angkasa.

Wahyono, T., \& Farahsani, Y. (2017). Penerapan pendekatan proses untuk meningkatkan keterampilan berbicara bahasa indonesia bagi penutur asing. AKSIS: Jurnal Pendidikan Bahasa dan Sastra Indonesia, 1(2), 204-220.

Wibowo, S. A., \& Roysa, M. (2018). Efektivitas penggunaan model think talk write berbantuan media komik strip dalam peningkatan keterampilan menulis dialog sederhana siswa kelas V SD 1 Tritis. KREDO: Jurnal Ilmiah Bahasa dan Sastra, l(2), 145-159.

Yunita, T. R. (2017). Strategi debat aktif dengan media komik tanpa teks dalam pembelajaran berbicara bahasa indonesia bagi penutur asing tingkat A2. (Skripsi). Universitas Pendidikan Indonesia. 